УДК $343.985-058.53$

DOI https://doi.org/10.32837/pyuv.v1i4(29).421

\author{
М.О. Ларкін \\ orcid.org/0000-0002-4676-460X \\ кандидат юридичних наук, доцент, \\ доиент кафедри кримінального права та правосуддя \\ Запорізького національного університету
}

\title{
ТАКТИЧНІ ОПЕРАЦІЇ ПІД ЧАС РОЗСЛІДУВАННЯ ЗЛОЧИНІВ, ЩО ВЧИНЯЮТЬСЯ ЧЛЕНАМИ МОЛОДІЖНИХ НЕФОРМАЛЬНИХ ГРУП (ОБ'ЄДНАНЬ)
}

Розслідування злочинів, що вчиняються членами молодіжних неформальних груп (об'єднань), вимагає від слідчого (прокурора) використання всіх наявних у криміналістиці тактико-криміналістичних прикладних конструкцій, однією 3 яких $є$ тактична операція. Так, Р.С. Бєлкін, підсумовуючи ідеї А.В. Дулова, які, без перебільшення, відіграють визначальну роль у теорії тактичних операцій, писав: «В наявному вигляді криміналістична тактика не відповідає потребам слідчої практики через те, що обмежується розробленням рекомендацій, розрахованих на окремі слідчі дії. Слідчому ж часто доводиться вирішувати завдання, за якими відповідь може бути знайдена тільки шляхом проведення серії слідчих, оперативно-розшукових, ревізійних та інших дій. Звідси - необхідність розробляти тактичні рекомендації для оптимального вирішення завдань загального характеру, що потребують для своєї реалізації проведення групи слідчих, оперативно-розшукових, ревізійних дій. Такі спільні завдання позначаються поняттям «тактичні операції»» [1, с. 519]. I тут Р.С. Бєлкін абсолютно аргументовано вказує на те, що «у концепції А.В. Дулова є одна суттєва суперечність: тактичними операціями він називав завдання більш-менш загального характеру, що виникають у процесі розслідування, а не засоби розв'язання цих завдань [1, с. 520], адже «операція - це сукупність узгоджених i взаємопов'язаних дій за розробленим планом» [2, с. 906], у жодному разі не «завдання». Тактична операція, відповідно, є засобом вирішення завдань, які стоять перед слідчим (прокурором), і являє собою «систему однойменних або різнойменних, процесуальних або непроцесуальних дій і заходів (слідчих, оперативно-розшукових, організаційних), які спрямовані на вирішення проміжного завдання розслідування, об'єднані єдиним планом і єдиним задумом, характеризуються вибірковістю і ситуаційною обумовленістю та виконуються правомочними посадовими особами під керівництвом слідчого» [3, с. 22].

Слушно наголошує I.В. Смаль, що важливо, щоби розслідування злочину починалося якомога раніше з моменту його вчинення. Така діяльність потребує на початку розслідування здійснення спе- цифічного комплексу слідчих дій і оперативно-розшукових заходів, що повинен забезпечити збір у найкоротші терміни такого обсягу доказів, які б цілком викрили винного у скоєнні цього злочину. Цей комплекс дій - тактична операція [4, с. 55].

Значний внесок у розроблення теорії тактичних операцій зробили такі вчені-криміналісти, як: О.Я. Баєв, В.П. Бахін, Р.С. Бєлкін, П.Д. Біленчук, Л.Я. Драпкін, А.В. Дулов, Г.А. Матусовський, В.О. Образцов, С.Б. Россинський, М.В. Салтевський, В.М. Шевчук, В.Ю. Шепітько, В.І. Шиканов, М.П. Яблоков та ін.

Метою статті є визначення особливостей змісту окремих тактичних операцій під час розслідування злочинів, що вчиняються членами молодіжних неформальних груп (об’єднань).

Сучасна криміналістична наука пропонує досить широкий спектр тактичних операцій, проте саме специфіка злочинних посягань, щодо яких здійснюється розслідування, зумовлює їх вибір. Суттєві ознаки тактичної операції такі: 1) системність взаємопов'язаних слідчих (розшукових) дій, організаційно-технічних та інших дій (заходів) алгоритмічного характеру; 2) зумовленість цієї системи дій слідчою та судовою ситуацією на певному етапі кримінального провадження; 3) спланованість тактичної операції, тобто дії та заходи такої операції провадяться за єдиним планом; 4) керівна (управлінська) роль слідчого, прокурора (за винятком оперативно-тактичних операцій, де керівником може бути і посадова особа оперативних підрозділів); 5) спрямованість дій та заходів на вирішення окремого тактичного (проміжного) завдання в досудовому розслідуванні [5, с. 233-234].

Аналіз практики розслідування злочинів, що вчиняються членами молодіжних неформальних груп (об'єднань), дозволяє виокремити три тактичні операції, у проведенні яких може виникнути необхідність, зумовлена розвитком слідчої ситуації та специфікою злочинних проявів:

1. «Захист свідка». $€$ припущення, що існують дві тактичні операції, здійснення яких обов'язкове в усіх кримінальних провадженнях незалежно від того, до якого виду або категорії належить злочин, що розслідується, і в якій слідчій ситуації розглядається: «Захист доказів» і «Перевірка 
показань особи, яка визнає себе винною у вчиненні злочину» [5, с. 248], що обгрунтовується в роботах В.В. Трухачова [7], О.Я. Баєва [8].

Варто погодитися 3 B.I. Бояровим у тому, що тактичну операцію «Захист свідка» (як і «Захист потерпілого») можна розглядати як таку, що здійснюється в рамках першої з названих обов' язкових тактичних операцій («Захист доказів») [9, с. 202].

Тактична операція «Захист свідка» притаманна розслідуванню групових злочинів, зокрема й розслідуванню кримінальної активності неформальної молоді. Слідчий (прокурор) ухвалює рішення про проведення зазначеної тактичної операції на підставі наявної вихідної інформації, якщо існує загроза життю, здоров'ю свідка (його близьких родичів), майну, репутації тощо. А.О. Масалітін слушно, на нашу думку, зазначає, що передувати ухваленню рішення про проведення вказаної тактичної операції може наявність однієї із двох типових слідчих ситуацій: 1) коли дані про свідка, який викриває винних, відомі підозрюваним, обвинуваченим (їхньому оточенню); 2) коли зазначені дані відомі лише слідчому (прокурору), а для інших ця особа залишається невідомою [10, с. 109].

Для розслідування злочинів, що вчиняються членами молодіжних неформальних груп (об’єднань), більш характерна перша слідча ситуація, адже здебільшого слідчим на початку розслідування не вживаються заходи щодо приховування особи свідка. I саме через це у більш ніж 60\% випадків здійснюються спроби впливу на показання свідків із метою невикриття членів неформального співтовариства. Такі спроби можуть здійснюватися «однодумцями» із неформального середовища, родичами підозрюваного (підозрюваних), зокрема через адвокатів.

Зазначена тактична операція, під час розслідування аналізованої категорії злочинів, на нашу думку, повинна передбачати: 1) проведення комплексу слідчих (розшукових) дій, оперативно-розшукових та організаційних заходів (це допит (допити) учасників кримінального провадження, окремі негласні слідчі (розшукові) дії, оперативно-розшукові заходи, подання запитів, клопотань, заяв до органів, установ тощо); 2) безпосереднє застосування заходів безпеки, передбачених Законом України «Про забезпечення безпеки осіб, які беруть участь у кримінальному судочинстві».

2. «Встановлення особи підозрюваного та його затримання». Потреба у проведенні цієї тактичної операції виникає на початку досудового розслідування, коли слідчий володіє мінімальним об’ємом інформації щодо того, який злочин учинено, а такоже припущення про причетність до нього молодіжного неформального угруповання.

Структурними компонентами зазначеної тактичної операції під час розслідування злочинів, що вчиняються членами молодіжних неформаль- них груп (об'єднань), може бути: 1) затримання підозрюваного «по гарячих слідах» під час спроби приховатися від органів, які здійснюють досудове розслідування; 2) проведення негласних слідчих (розшукових) дій і оперативно-розшукових заходів для встановлення місця перебування чи мешкання підозрюваної особи; 3) огляд місця подіï; 4) допит свідка (свідків); 5) допит потерпілого (потерпілих); 6) проведення обшуку (обшуків); 7) допит підозрюваного (підозрюваних).

3. «Нейтралізація протидії розслідуванню». Ураховуючи резонансність кримінальної активності неформальної молоді, органи слідства в більш ніж 60\% випадків стикаються з різноманітними формами протидії розслідуванню щодо: 1) учасників кримінального провадження (наприклад, спроби впливу на потерпілого, свідка, експерта, перекладача, слідчого, прокурора шляхом погроз, підкупу тощо); 2) обставин учинення злочину (намагання знищити окремі сліди, заплутати слідство шляхом надання неправдивої інформації, підроблених чи сфальсифікованих документів тощо).

Є.Г. Сахарова слушно підкреслює, що нейтралізація протидії розслідуванню має складатися із двох етапів: 1) виявлення здійснюваної або такої, що готується, протидії; 2) іï подолання та саме нейтралізації [11, с. 151]. Це, на нашу думку, й зумовлює структурні компоненти тактичної операції, яка спрямована на нейтралізацію протидії розслідуванню.

Отже, такими компонентами можуть бути:

- проведення негласних слідчих (розшукових) дій і оперативно-розшукових заходів;

- проведення слідчих (розшукових) дій;

- ужиття заходів щодо безпеки учасників кримінального провадження;

- направлення запитів до різних підприємств, установ, організацій тощо;

- проведення прес-конференцій тощо.

Отже, ситуаційна зумовленість процесу розслідування злочинів, що вчиняються членами молодіжних неформальних груп (об’єднань), може вимагати від слідчого (прокурора) застосування такої тактико-криміналістичної форми, як тактична операція. Так, нами запропоновані три види тактичних операцій, які спрямовані на вирішення окремих завдань і оптимізацію досудового розслідування.

\section{Jimepamypa}

1. Белкин Р.С. Избранные труды. Москва : Нормa, 2008. $768 \mathrm{c.}$

2. Сучасний тлумачний словник української мови : 60000 слів / уклад. Н.Д. Кусайкіна, Ю.С. Цибульник ; за заг. ред. В.В. Дубічинського. Харків : ВД «Школа», 2014. $784 \mathrm{c.}$

3. Здоровко С.Ф. Тактичні операції при розслідуванні вбивств, що вчиняються організованими 
групами і злочинними організаціями : дис. ... канд. юрид. наук: 12.00.09. Харків, 2002. 210 с.

4. Смаль I.В. Методика розслідування підроблення проїзних квитків : дис. ... канд. юрид. наук: 12.00.09. Донецьк, 2007. 203 с.

5. Криміналістика : підручник : у 2-х т. / В.Ю. Шепітько й ін. ; за ред. В.Ю. Шепітька. Харків : Право, 2019. Т. 1. 456 с.

6. Криміналістика. Академічний курс : підручник / Т.В. Варфоломеєва та ін. Київ : Юрінком-Інтер, 2011. 504 c.

7. Трухачёв В.В. Преступное воздействие на доказательственную информацию: правовые и криминалистические средства предупреждения, выявления и нейтрализации / научн. ред. : О.Я. Баев. Воронеж : Изд-во Воронежского гос. ун-та, 2000. 232 с.

8. Баев О.Я. Основы криминалистики : курс лекций. Москва : Экзамен, 2001. 288 с.

9. Бояров B.I. Деякі питання допиту свідків у кримінальних провадженнях про екстремістську діяльність. Право і суспільство. 2017. № 3/1. С. 199-204.

10. Масалітін А.О. Розслідування злочинів, що вчиняються учасниками угруповань футбольних уболівальників : дис. ... канд. юрид. наук: 12.00.09. Київ, 2019. 190 c.

11. Сахарова Е.Г. Расследование причинения вреда здоровью : монография / под ред. В.П.Лаврова. Москва : Юрлитинформ, 2007. 193 с.

\section{Анотація}

Ларкін М. О. Тактичні операції під час розслідування злочинів, що вчиняються членами молодіжних неформальних груп (об'єднань). - Стаття.

У статті наголошується, що розслідування злочинів, які вчиняються членами молодіжних неформальних груп (об'єднань), вимагає від слідчого (прокурора) використання всіх наявних у криміналістиці тактико-криміналістичних прикладних конструкцій, однією з яких є тактична операція.

Аналіз практики розслідування злочинів, що вчиняються членами молодіжних неформальних груп (об'єднань), дозволяє виокремити три тактичні операціï, у проведенні яких може виникнути необхідність, зумовлена розвитком слідчої ситуації та специфікою злочинних проявів.

Тактична операція «Захист свідка» притаманна розслідуванню групових злочинів, зокрема й розслідуванню кримінальної активності неформальної молоді. Слідчий (прокурор) ухвалює рішення про проведення зазначеної тактичної операції на підставі наявної вихідної інформації, якщо існує загроза життю, здоров'ю свідка (його близьких родичів), майну, репутації тощо. Зазначена тактична операція, під час розслідування аналізованої категорії злочинів, повинна передбачати: 1) проведення комплексу слідчих (розшукових) дій, оперативно-розшукових і організаційних заходів (це допит (допити) учасників кримінального провадження, окремі негласні слідчі (розшукові) дії, оперативно-розшукові заходи, подання запитів, клопотань, заяв до органів, установ тощо); 2) безпосереднє застосування заходів безпеки, передбачених Законом України «Про забезпечення безпеки осіб, які беруть участь у кримінальному судочинстві» .

Потреба у проведенні тактичної операції «Встановлення особи підозрюваного та його затримання» виникає на початку досудового розслідування, коли слідчий володіє мінімальним об'ємом інформації щодо того, який злочин вчинено, а також припущення про причетність до нього молодіжного неформального угруповання. Структурними компонентами зазначеної тактичної операції під час розслідування злочинів, що вчиняються членами молодіжних неформальних груп (об'єднань), може бути: 1) затримання підозрюваного «по гарячих слідах» під час спроби приховатися від органів, які здійснюють досудове розслідування; 2) проведення негласних слідчих (розшукових) дій i оперативно-розшукових заходів для встановлення місця перебування чи мешкання підозрюваної особи; 3) огляд місця подіï; 4) допит свідка (свідків); 5) допит потерпілого (потерпілих); 6) проведення обшуку (обшуків); 7) допит підозрюваного (підозрюваних).

Ураховуючи резонансність кримінальної активності неформальної молоді, органи слідства в більш ніж $60 \%$ випадків стикаються 3 різноманітними формами протидії розслідуванню. Структурними компонентами тактичної операції «Нейтралізація протидії розслідуванню» можуть бути: проведення негласних слідчих (розшукових) дій і оперативно-розшукових заходів; проведення слідчих (розшукових) дій; ужиття заходів щодо безпеки учасників кримінального провадження; направлення запитів до різних підприємств, установ, організацій тощо; проведення прес-конференцій тощо.

Ключові слова: тактична операція, розслідування, злочин, молодь, неформальна група, неформальне об'єднання.

\section{Summary}

Larkin M. O. Tactical operations in the investigation of crimes committed by members of youth informal groups (associations). - Article.

The article emphasizes that the investigation of crimes committed by members of youth informal groups (associations) requires the investigator (prosecutor) to use all available tactical and criminalist applied structures, one of which is a tactical operation.

Analysis of the practice of investigating crimes committed by members of youth informal groups (associations) allows to distinguish three tactical operations, which may be necessary due to the development of the investigative situation and the specificity of criminal manifestations.

The tactical operation "Witness protection" is inherent in the investigation of group crimes, in particular the investigation of criminal activity of informal youth. The investigator (prosecutor) makes the decision to conduct the specified tactical operation on the basis of the available background information if there is a threat to the life, health of the witness (his close relatives), property, reputation, etc. This tactical operation, when investigating the analyzed category of crimes, should include: 1) conducting a complex of investigative (searching) actions, operative-investigative and organizational measures (this is the interrogation (interrogations) of participants of criminal proceedings, some unspoken investigative (searching) actions, operative-investigative measures, filing of requests, petitions, applications to bodies, institutions, etc.); 2) direct application of the security measures provided by the Law "On ensuring the safety of persons involved in criminal proceedings".

The need to conduct a tactical operation to identify and apprehend a suspect arises at the beginning of a pretrial investigation, when the investigator has a minimal amount of information about the crime and is suspected of involvement in a youth informal group. The structural components of this tactical operation in the investigation of crimes committed by members of youth informal groups (associations) may be: 1) apprehending the suspect in hot 
pursuit while attempting to hide from the authorities conducting the pre-trial investigation; 2) conducting unspoken investigative (search) actions and operativesearch measures for establishing the location or residence of the suspected person; 3) an overview of the scene; 4) interrogation of the witness $(\mathrm{s})$; 5) questioning the victim (s); 6) conducting a search (searches); 7) interrogation of the suspect (suspects).

Given the resonance of criminal activity of informal youth, in more than $60 \%$ of cases, investigative bodies are confronted with various forms of counteraction to the investigation. Structural components of the tactical operation "neutralization of counteraction to the investigation" may include: conducting of unspoken investigative (search) actions and operativesearch measures; conducting investigative (search) actions; taking measures on the safety of participants in criminal proceedings; sending requests to different companies, institutions, organizations, etc; holding press conferences, etc.

Key words: tactical operation, investigation, youth, crime, informal group, informal association. 